\title{
The Maximum Length Record of the Blackspot Seabream (Pagellus bogaraveo Brünnich, 1768) for the Entire Aegean Sea and Turkish Territorial Waters
}

\author{
Şenol Paruğ $\breve{g}^{1, a, *}$, Özgür Cengiz ${ }^{2, b}$ \\ ${ }^{1}$ Fisheries Faculty, Kastamonu University, 37200 Kastamonu, Turkey \\ ${ }^{2}$ Fisheries Faculty, Van Yüzüncü Yll University, 65080 Van, Turkey
}

*Corresponding author

\begin{tabular}{l|l}
\hline ARTICLE INFO & A \\
\hline Research Article & The
\end{tabular}
A B S T R A C T

The maximum length, weight, and age information of organisms in an ecosystem, moreover, the first records of migrated exotic species are essential in terms of the basis for the studies on population dynamics, stock assessment, and biological activities. Therefore, the recording of such data may be

Received : $11 / 05 / 2020$

Accepted : 29/06/2020 necessary for scientific databases and new related studies. The Blackspot seabream (Red seabream Pagellus bogaraveo), which belongs to the Sparidae family, is an important seafood which is marketed fresh and frozen around the Mediterranean and the Aegean seas. Nowadays, this species has high prices depending on market demands in domestic markets as a result of overfishing and is also cultured in northern Spain. It is classified as "Near Threatened Species" in the red list due to its decreasing population trend by the IUCN. A single specimen of the Blackspot seabream with 30.7

Keywords: $\mathrm{cm}$ in total length and $390.00 \mathrm{~g}$ in total weight, which was angled in the Saros Bay with a handline Sparidae Pagellus bogaraveo Blackspot Seabream Maximum Length by a fisherman on February 08, 2019, was obtained from a fishmonger in Çanakkale. Even though there are bigger individuals in the North-east Atlantic probably depending on polar and/or deep-sea gigantism, the mentioned measurement is the proven maximum total length of this species for the Aegean Sea Aegean Sea up to the time.

Türk Tarım - Gıda Bilim ve Teknoloji Dergisi, 8(10): 2125-2130, 2020

\section{Tüm Ege Denizi ve Türk Karasuları için Mandagöz Mercan'ın (Pagellus bogaraveo Brünnich, 1768) Maksimum Total Boy Kaydı}

\begin{tabular}{|c|c|}
\hline M A K A L E B İ L G İ S İ & Ö Z \\
\hline $\begin{array}{l}\text { Anahtar Kelimeler: } \\
\text { Sparidae } \\
\text { Pagellus bogaraveo } \\
\text { Mandagöz Mercan } \\
\text { Maksimum Boy } \\
\text { Ege Denizi }\end{array}$ & $\begin{array}{l}\text { Bir ekosistemdeki canlılara ait maksimum boy, ağırlık ve yaşın bilinmesi, ayrıca göç ile gelen yabanc1 } \\
\text { türlerin ilk kayıtlarının oluşturulması; popülasyon dinamiği, stok tahmini ve biyolojik aktiviteler } \\
\text { üzerine yapılan çalışmaların temelini oluşturması açısından önemlidir. Bu nedenle, bu tür verilerin } \\
\text { kaydedilmesi, bilimsel veri tabanı oluşurulabilmesi ve tür ile ilgili yeni çalışmalar için gerekli } \\
\text { olabilir. Sparidae familyasının bir türü olan Mandagöz mercan (Pagellus bogaraveo), Akdeniz ve Ege } \\
\text { çevresinde taze ve dondurulmuş olarak pazarlanan önemli bir deniz ürünüdür. Günümüzde bu tür, } \\
\text { aşırı avlanma sonucu iç piyasalardaki taleplere bağlı olarak yüksek fiyatlara sahiptir ve kuzey } \\
\text { İspanya'da kültürü de yapılmaktadır. Azalan populasyon eğilimi nedeniyle, IUCN tarafindan kırmız1 } \\
\text { listede, Yakın Tehdit Altındaki Türler (NT) listesine dahil edilmiştir. 08 Şubat } 2019 \text { tarihinde, bir } \\
\text { balıkçı tarafından Saroz Körfezi’nde olta ile yakalanan } 30,7 \mathrm{~cm} \text { total boya ve } 390,00 \text { gr ağırlığa sahip } \\
\text { bir adet Mandagöz mercan balığı, Çanakkale'deki bir balık satıcısından temin edilmiştir. Muhtemelen } \\
\text { polar ve/veya derin deniz gigantizmine bağlı olarak Kuzey Doğu Atlantik’te daha büyük bireyler olsa } \\
\text { da, söz konusu ölçüm, bu türün Ege Denizi için kanıtlanmış şu ana kadarki en büyük total boy } \\
\text { değeridir. }\end{array}$ \\
\hline
\end{tabular}




\section{Introduction}

The Sparidae, commonly called sea breams and porgies, is a family of the order Perciformes and contains 164 species in 38 genera (Eschmeyer's Catalog of Fishes, 2020; Fishbase, 2020a). Recently, the sister family Centracanthidae (picarels) has also been merged with the Sparidae (Santini et al., 2014; Fishbase, 2020b) while they previously were listed as distinct and separate (Nelson 2006; Golani et al., 2006; Mater et al., 2011). As far as it is known, 24 Sparidae species within 13 genera (Boobs, Centracanthus, Dentex, Diplodus, Evynnis Lithognathus, Oblada, Pagellus, Pagrus, Sarpa, Sparus, Spicara and Spondyliosoma) from Turkish territorial waters were reported (Mater et al., 2011; Fishbase, 2020c) and there are two more species (Crenidens crenidens and Rhabdosargus haffara) in the Eastern Mediterranean (Golani et al., 2006) which are lessepsian. Members of the Sparidae family are mainly coastal marine fishes which have high economic value and are captured and cultured for human consumption, as well as for recreational intentions (Pavlidis and Mylonas, 2011). According to the FAO statistics, in terms of captured marine and brackish water fishes all over the world in 2018, the Sparidae production with 347,996 metric tonnes $(\mathrm{mtn})$ represented \%0.48 of the total amount. On the other hand, aquaculture production of the Sparidae in 2018 reached 388,534 $\mathrm{mtn}$ with a revenue of $\$ 1,843,265,000$ which represented $12.92 \%$ of the amount and $14.24 \%$ of the value of the production of cultured and farmed (tuna fish, etc.) marine fishes worldwide (FAO, 2020).

The Blackspot seabream (Red seabream - Pagellus bogaraveo Brünnich, 1768), belongs to the family Sparidae, is a demersal and omnivorous (predominantly carnivores) teleost fish feeding mainly on crustaceans, mollusks, worms, small fish, and sometimes on plants (Wheeler, 1997; Froese and Pauly, 2019). They live near the coast as juveniles and on the continental slope down to 400 meters in the Mediterranean but down to 700-800 meters in the Atlantic as adults, above different types of substrates, like mud, sand, and rocks (Fischer et al. 1987; Froese and Pauly, 2019). This species prevalently shows the protandrous hermaphroditic feature in culture conditions while a high incidence of gonochorism occurred in the wild (Micale et al., 2011). It is relatively widespread species from the south of Norway to the west of Saharan Africa, including the Azores and Canary Islands in the continental slope of Atlantic, and is more common in the western Mediterranean Sea than in the eastern basin, besides it is absent in the Black Sea (Spedicato et al., 2002; IUCN, 2014) (Figure 1). In addition, it has been recorded that the total length of individuals, especially in northeastern of the Atlantic, is higher (Bauchot and Hureau, 1986; Froese and Pauly, 2019) compared to the Mediterranean basin records (İşmen et al., 2007; Karachle and Stergiou, 2008). This situation may be related to the abundance of nutrients and/or the polar gigantism biological incident.

Nowadays, the Blackspot seabream has high prices depending on market demands in domestic markets as a result of overfishing and is also cultured in northern Spain (IUCN, 2014; FAO, 2017). Nevertheless, probably due to problems such as high sensitivity to captivity conditions, slow growth rate and late maturation age, only one commercial enterprise produces this fish (Pavlidis and Mylonas, 2011). Also, the annual aquaculture production amount of this species decreased from $245 \mathrm{mtn}$ to $108 \mathrm{mtn}$ from 2011 to 2018 (FAO, 2020) (Table 1). Pagellus bogaraveo has also been included in the list of the Near Threatened Species by the IUCN since 2014 due to its decreasing population trend (IUCN, 2014).

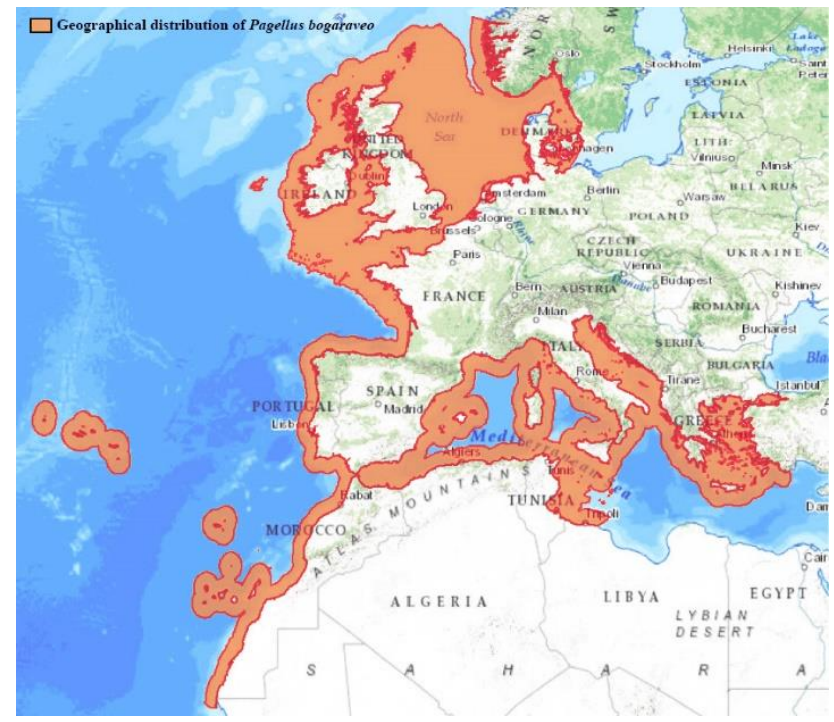

Figure 1. Geographic distrubition of Pagellus bogaraveo (modified from IUCN, 2014)

Table 1. Worldwide production amount of $P$. bogaraveo depending on years (prepared using FAO statistics; FAO, 2020)

\begin{tabular}{c|cc}
\hline \multirow{2}{*}{ Year } & \multicolumn{2}{|c}{ Production amount } \\
\cline { 2 - 3 } & $\begin{array}{c}\text { Production } \\
\text { amount (mtn) of } \\
\text { captured fish }\end{array}$ & $\begin{array}{c}\text { Production } \\
\text { amount (mtn) of } \\
\text { cultured fish }\end{array}$ \\
\hline 2000 & 1876 & 0 \\
2001 & 1313 & 0 \\
2002 & 1693 & 2 \\
2003 & 1603 & 22 \\
2004 & 1601 & 100 \\
2005 & 2261 & 118 \\
2006 & 1517 & 134 \\
2007 & 1697 & 194 \\
2008 & 1606 & 225 \\
2009 & 1479 & 183 \\
2010 & 1252 & 214 \\
2011 & 1070 & 245 \\
2012 & 1082 & 186 \\
2013 & 1390 & 228 \\
2014 & 1620 & 172 \\
2015 & 1634 & 171 \\
2016 & 1339 & 178 \\
2017 & 2601 & 142 \\
2018 & 1385 & 108 \\
\hline
\end{tabular}

Maximum length and weight are important parameters used in life history studies and fisheries science (Dulčić and Soldo, 2005). These measurements are applied directly or indirectly in most stock assessment models (Borges 2001; Cengiz 2014). Notably, the size-based analyses of 
fishes are becoming increasingly popular methods for enhancing the understanding of community structure and function (Jennings and Dulvy, 2005) and could be used as a tool for rapid assessment of growth rates in the deficiency of primary data (Filiz and Sevingel, 2015). Therefore, it is important to regularly update the maximum size information of commercially or recreationally important species (Dulčić and Soldo, 2006; Navarro et al., 2012; Cengiz et al., 2019a). Depending on polar or deep-sea gigantism (Geldiay and Kocataş, 2012), there are massive individuals, especially in the seas with lower average temperatures; but the previous maximum total length record for the Aegean Sea was $25.1 \mathrm{~cm}$ (İşmen et al., 2007). This study presents the maximum length and weight values of the Blackspot seabream for the Aegean Sea up to the time.

\section{Material and Methods}

Saros Bay, situated in the Northeastern Aegean Sea, is connected to the North Aegean with a depth of approximately $600 \mathrm{~m}$ to the west. The shelf extends at a water depth of 90-120 m. The length of the bay is about 61 $\mathrm{km}$ and the width at the opening to the Aegean Sea is about $36 \mathrm{~km}$ (Eronat and Sayın, 2014; Cengiz et al., 2019b). Since Saros Bay had been closed to bottom trawl fishing since 2000 (Cengiz et al., 2011) and no industrial activity was prevalent in the area (Sarı and Çağatay, 2001), the bay can be considered as a pristine environment (Cengiz et al., 2013; 2019c).

A single specimen of Pagellus bogaraveo was caught in Saros Bay (Figure 2) by a fisherman on 08 February 2019, from a depth of $25 \mathrm{~m}$, using live bait (mud-shrimp; Upogebia pusilla or Gilvossius tyrrhenus) with a $0.50 \mathrm{~mm}$ monofilament fishing line, consisting of 3 pieces of number 3 Mustad 505 hooks and lead weights. Subsequently, we obtained it from a fishmonger in Çanakkale.

Total length is defined as the measurement taken from the anterior-most part of the fish to the end of the caudal fin rays when compressed dorso-ventrally (Anderson and Gutreuter 1983). Accordingly, the total length and weight of the specimen was measured accurately. Besides, some morphometric characters (according to Figure 3) were measured, and some meristic characters were counted.

\section{Results and Discussion}

The blackspot seabream specimen (Figure. 4) subjected to the article was $30.7 \mathrm{~cm}$ in total length and $390.00 \mathrm{~g}$ in total weight. Some morphometric and meristic characters for $P$. bogaraveo is presented in Table 2. The comparison of the maximum lengths and weights recorded for $P$. bogaraveo in the Aegean Sea is given in Table 3.

As well known, the individuals in populations exposed to high levels of fishing pressure will respond by reproducing at smaller average sizes and ages, and so reached maximum lengths would gradually decrease. Nevertheless, despite overfishing, sometimes such large individuals which could not be caught because of noncoincidence, are also encountered (Filiz 2011; Cengiz et al., 2019d). On the other hand, some factors such as nutrient availability and abundance, feeding appetence, water temperature, photoperiod, dissolved oxygen amount, salinity, turbidity, pollutants, the severity of water current, predator density, intra-specific social interactions, and genetics, might affect the growth (Helfman et al., 2009; Geldiay and Kocataş, 2012; Acarlı et al., 2009). Briefly, the maximum length and weight of organisms depend on the ecological conditions, regional differences, and overfishing pressure.

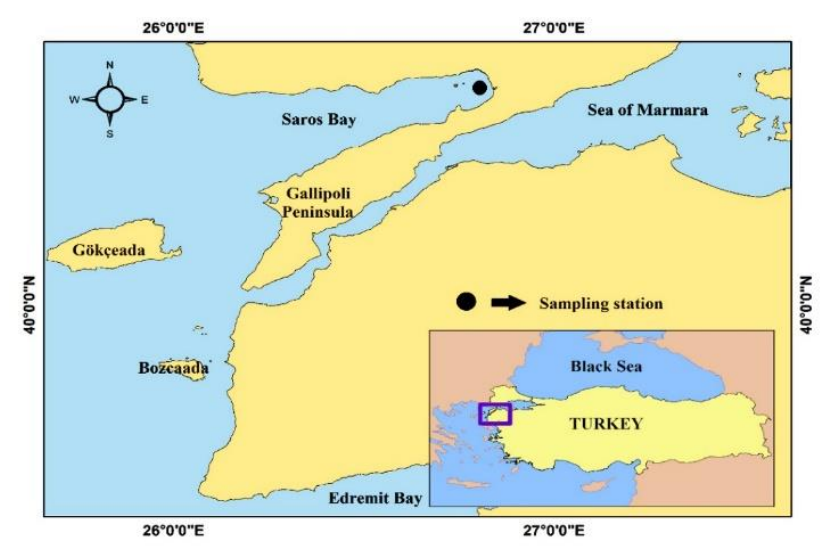

Figure 2. Saros Bay and sampling station

Table 2. Some morphometric and meristic characters of the $P$. bogaraveo specimen discussed in this study

\begin{tabular}{l|c}
\hline \multicolumn{1}{c|}{ Morphometric characters } & Value \\
\hline Weight $(\mathrm{g})$ & 390.0 \\
TL $(\mathrm{mm})$ & 307.0 \\
FL $(\mathrm{mm})$ & 274.1 \\
SL $(\mathrm{mm})$ & 251.9 \\
BDm $(\mathrm{mm})$ & 23.0 \\
BDx $(\mathrm{mm})$ & 96.3 \\
HL $(\mathrm{mm})$ & 75.9 \\
PrOD (mm) & 11.1 \\
ED (mm) & 28.2 \\
POD (mm) & 36.6 \\
PrPD (mm) & 82.7 \\
DFBL (mm) & 114.8 \\
PFBL (mm) & 77.8 \\
AFBL (mm) & 42.2 \\
CPL (mm) & 35.0 \\
$\quad$ Meristic characters & \\
Dorsal fin rays & XII - 12 \\
Anal fin rays & 14 \\
Pectoral fin rays & \\
\hline
\end{tabular}

There is a consensus among naturalists that data on maximum length, weight, age, growth, and weight-length relationship are required to estimate the population parameters as asymptotic length and growth coefficient of fish, which is essential for fisheries resource planning and management (Agüero et al. 2010; Cengiz et al., 2019e). Consequently, this paper provides new information on the maximum proved total length of $P$. bogaraveo for the entire Aegean Sea and Turkish territorial waters and the second-rank maximum total length for the Mediterranean Basin. The information presented here may be used to compare the similar parameters in ongoing fishery studies all over the world by providing scientific support to the fisheries scientists. 


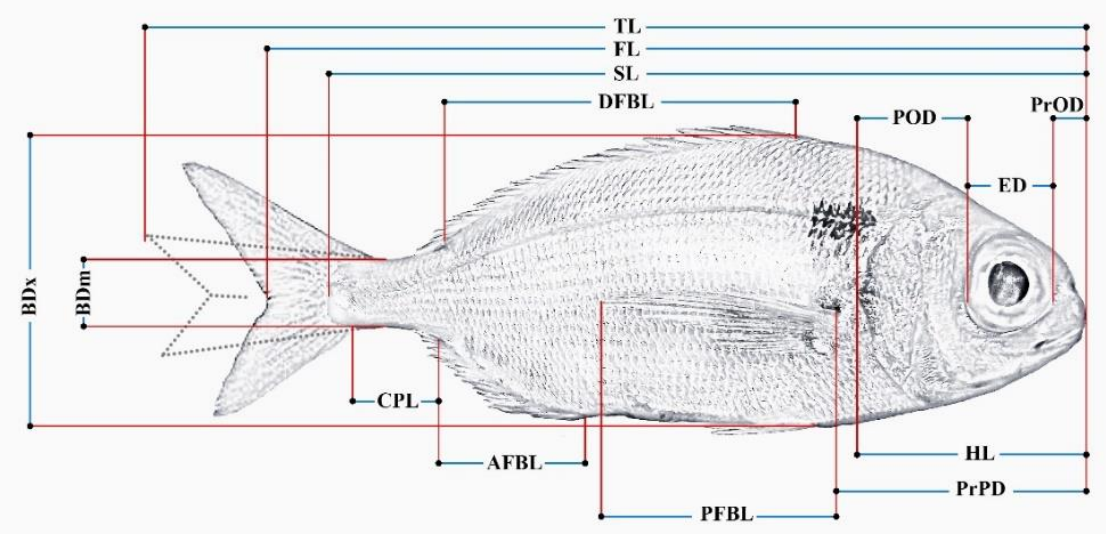

Figure 3. Morphometric measurements of the Blackspot seabream

Abbreviations: TL - total length, FL - fork length, SL - standard length, HL - head length, PrOD - preorbital distance, ED - eye diameter, POD postorbital distance, PrPD - prepectoral distance, DFBL - dorsal fin base length, PFBL - pectoral fin base length, AFBL - anal fin base length, CPL - caudal peduncle length, BDm - minimum body depth, BDx - maximum body depth.

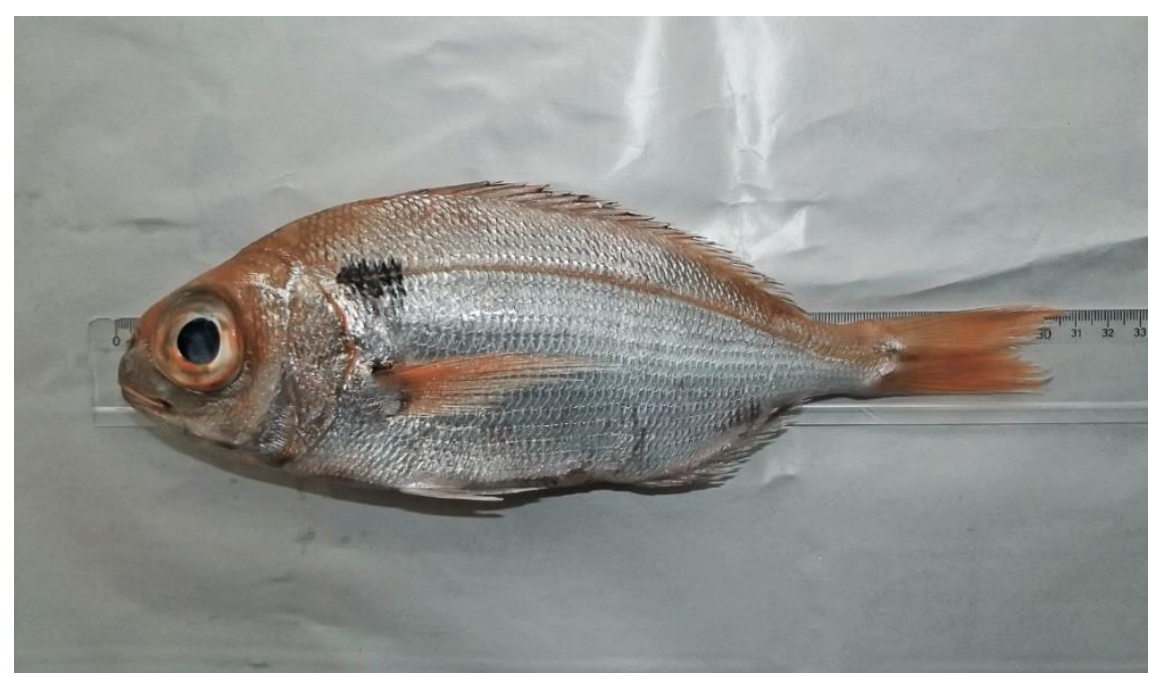

Figure 4. The Blackspot seabream with $30.7 \mathrm{~cm}$ TL and $390.00 \mathrm{~g}$ TW

Table 3. The comparison of the maximum length and weight records of P. bogaraveo caught in the Aegean Sea

\begin{tabular}{l|lccc}
\hline \multicolumn{1}{c|}{ Authors } & \multicolumn{1}{c}{ Location } & $\mathrm{N}$ & $\mathrm{L}_{\max }(\mathrm{cm})$ & $\mathrm{W}_{\max }(\mathrm{g})$ \\
\hline Papaconstantinou et al. (1994) & Northern Aegean Sea, Greece & 694 & 17.5 & - \\
Karakulak et al. (2006) & Gökçeada Island, Turkey & 1 & 18.6 & 66.80 \\
İşmen et al. (2007) & Saros Bay, Turkey & 2355 & 25.1 & 255.00 \\
Özaydın et al. (2007) & İzmir Bay, Turkey & 51 & 17.9 & - \\
İlkyaz et al. (2008) & İzmir Bay, Turkey & 77 & 15.1 & - \\
Karachle and Stergiou (2008) & Northern Aegean Sea, Greece & 72 & 23.1 & - \\
Cengiz (2013) & Gallipoli Peninsula, Turkey & 92 & 20.9 & 105.62 \\
Bilge et al. (2014) & Southern Aegean Sea, Turkey & 113 & 15.9 & - \\
Altın et al. (2015) & Gökçeada Island, Turkey & 471 & 5.7 & 1.68 \\
This study & Saros Bay, Turkey & 1 & 30.7 & 390.00 \\
\hline
\end{tabular}

\section{Ethical Approval}

The confirmation document, numbered 16498365-050E.6917, and indicates the Ethics Committee's permission is not required for this study (scientific studies with dead fish provided from commercial fishers) was obtained from the Local Ethics Committee of Kastamonu University.

\section{Acknowledgments}

The authors would like to thank the fishmonger Engin TUNÇ and the academician Semih KALE for their aid.

\section{References}

Acarlı D, Kara A, Bayhan B, Çoker T. 2009. Catch composition and catch efficiency of species caught from Homa Lagoon (Izmir Bay, Aegean Sea). Ege Journal of Fisheries and Aquatic Sciences, 26(1): 39-47.

Agüero JDLC, Gomez VMC, Navarro JTN. 2010. New maximum size record for the chili sea catfish Notarius troschelii (Siluriformes: Ariidae) from the Tropical Eastern Pacific. Marine Biodiversity Records, 3: e107.

Altın A, Ayyıldız H, Kale S, Alver C. 2015. Length-weight relationships of 49 fish species from shallow waters of Gökçeada Island, Northern Aegean Sea. Turkish Journal of Zoology, 39: 1-5. 
Anderson RO, Gutreuter SJ. 1983. Length, weight, and associated structural indices. In: L Nielsen, and D Johnson D (eds.), Fisheries Techniques, American Fisheries Society, Bethesda, pp. 283-300. MD, USA.

Bauchot ML, Hureau JC. 1986. Sparidae. In: PJP Whitehead, ML Bauchot, JC Hureau, J Nielsen and E Tortonese (eds.), Fishes of the North-eastern Atlantic and the Mediterranean. volume 2, pp. 883-907. UNESCO, Paris.

Bilge G, Yapıcı S, Filiz H, Cerim H. 2014. Weight-length relations for 103 fish species from the Southern Aegean Sea, Turkey. Acta Ichthyologica et Piscatoria, 44: 263-269.

Borges L. 2001. A new maximum length for the Snipefish Macrohamphosus scolopax. Cybium, 25: 191-192.

Cengiz Ö, İşmen A, Özekinci U, Öztekin A. 2011. Saroz Körfezi (Kuzey Ege Denizi) balık faunası üzerine bir araştırma. Afyon Kocatepe Üniversitesi Fen Bilimleri Dergisi, 11: 31 37.

Cengiz Ö. 2013. Length-weight relationships of 22 fish species from the Gallipoli Peninsula and Dardanelles (northeastern Mediterranean, Turkey). Turkish Journal of Zoology, 37: 419-422.

Cengiz Ö, Özekinci U, İşmen A, Öztekin A. 2013. Age and growth of the four-spotted megrim (Lepidorhombus boscii Risso, 1810) from Saros Bay (Northern Aegean Sea, Turkey). Mediterranean Marine Science, 14(1): 36-44.

Cengiz Ö. 2014. A new maximum length record of the Bluefish (Pomatomus saltatrix Linnaeus, 1766) for Turkey Seas. Bitlis Eren Üniversitesi Fen Bilimleri Dergisi, 3: 113-116.

Cengiz Ö, Kızılkaya B, and Paruğ ŞŞ. 2019a. Maximum size record of brown meagre (Sciaena umbra Linnaeus, 1758) for Aegean Sea. KSU Journal of Agriculture and Nature, 22(4): 659-663 (In Turkish).

Cengiz Ö, Paruğ ŞŞ, Kızılkaya B. 2019b. Occurrence of rudderfish (Centrolophus niger Gmelin, 1789) in Saroz Bay (Northern Aegean Sea, Turkey). Turkish Journal of Agriculture-Food Science and Technology, 7(5): 799-801.

Cengiz Ö, Paruğ, ŞŞ, Kızılkaya B. 2019c. Weight-length relationship and reproduction of Bogue (Boops boops Linnaeus, 1758) in Saros Bay (Northern Aegean Sea, Turkey). KSU Journal of Agriculture and Nature, 22(4): 577582 (In Turkish).

Cengiz Ö, Kızılkaya B, Paruğ ŞŞ. 2019d. Growth characteristics of annular seabream (Diplodus annularis Linnaeus, 1758) for Turkish Waters. KSU Journal of Agriculture and Nature, 22(5): 817-822 (In Turkish).

Cengiz Ö, Paruğ, ŞŞ, Kızılkaya B. 2019e. Maximum Length Record of Common Two-banded Seabream (Diplodus vulgaris Geoffroy Saint-Hilaire, 1817) for Aegean Sea with Turkish Waters. Alinteri J. of Agr. Sci., 34(2): 160-163.

Dulčić J, Soldo A. 2005. A new maximum length for the grey triggerfish, Balistes capriscus Gmelin, 1789 (Pisces: Balistidae) from the Adriatic Sea. Institute of Oceanography and Fisheries-Split Croatia, 88: 1-7.

Dulčić J, Soldo A. 2006. A new maximum length for the garpike Belone belone (Belonidae). Cybium, 30: 382.

Eronat C, Sayin E. 2014. Temporal evolution of the water characteristics in the bays along the eastern coast of the Aegean Sea: Saros, İzmir, and Gökova bays. Turkish Journal of Earth Sciences, 23: 53-66.

Eschmeyer's Catalog of Fishes. 2020. Species by family/subfamily in Eschmeyer's Catalog of Fishes (Online version - updated 02 June 2020). URL: http://researcharchive.calacademy.org/research/ichthyology/ catalog/SpeciesByFamily.asp\#Sparidae. (06/2020)

FAO. 2017. The State of World Fisheries and Aquaculture Opportunities and Challenges, Food and Agriculture Organization of The United Nations, Rome, Italy. URL: http://www.fao.org/fishery/countrysector/naso_spain/en. $(02 / 2020)$
FAO. 2020. The State of World Fisheries and Aquaculture Opportunities and Challenges, Food and Agriculture Organization of The United Nations, Rome, Italy. URL: http://www.fao.org/fishery/statistics/en. (06/2020)

Filiz H. 2011. A new maximum length for the red mullet, Mullus barbatus Linnaeus, 1758. Biyoloji Bilimleri Araştırma Dergisi, 4: 131-135.

Filiz H, Sevingel N. 2015. A new maximum length for the parrotfish, Sparisoma cretense (Linnaeus, 1758) in the Mediterranean Sea. Journal of Aquaculture Engineering and Fisheries Research, 1: 140-143.

Fishbase. 2020a. Family Sparidae - Porgies. URL: https://www.fishbase.se/summary/FamilySummary.php?ID= 330\#famList_tab. (06/2020)

Fishbase. 2020b. Family Centracanthidae - Picarels. URL: https://www.fishbase.in/summary/FamilySummary.php?ID= 461. (06/2020)

Fishbase. 2020c. All fishes reported from Turkey URL: https://www.fishbase.se/Country/CountryCheckList.php?res ultPage=1\&c_code=792. $(06 / 2020)$

Fischer ML, Bauchot ML, Schneider M. 1987. Fiches FAO d'identification des espèces pour les besoins de la peches, Vol. II, Mediterranèe et mer Noire. Zone de pêche, 37. Rome: Commission des Communautès Europèennes and FAO.

Froese R, Pauly D. (Eds) 2019. "Pagellus bogaraveo" in FishBase March 2020 version. URL: https://www.fishbase.de/ summary/890. (03/2020)

Geldiay R, Kocataş A. 2012. Deniz Biyolojisi ( $8^{\text {th }}$ ed). Dora Yayıncilik. 526 p.

Golani D, Öztürk B, Başusta N. 2006. Fishes of the Eastern Mediterranean. Turkish Marine Research Foundation (TÜDAV), İstanbul, Turkey, $259 \mathrm{p}$.

Helfman GS, Collatte BB, Facey DE, Bowen BW. 2009. The diversity of fishes: Biology, Evolution and Ecology ( $\left.2^{\text {nd }} \mathrm{ed}\right)$. Wiley-Blackwell, UK, $720 \mathrm{p}$.

IUCN. 2014. Carpenter KE, Russell B. Pagellus bogaraveo. The IUCN Red List of Threatened Species 2014: e.T170244A 1300216. http://dx.doi.org/10.2305/IUCN.UK.2014-3.RLTS. T170244A1300216.en URL: https://www.iucnredlist.org/ species/170244/1300216. (02/2020)

İlkyaz AT, Metin G, Soykan O, Kinacigil HT. 2008. Lengthweight relationship of 62 fish species from the Central Aegean Sea, Turkey. Journal of Applied Ichthyology, 24: 699-702.

İşmen A, Özen O, Altınağaç U, Özekinci U, Ayaz A. 2007. Weight-length relationships of 63 fish species in Saros Bay, Turkey. Journal of Applied Ichthyology, 23: 707-708.

Jennings S, Dulvy NK. 2005. Reference points and reference directions for size based indicators of community structure. ICES Journal of Marine Sciences, 67: 397-404.

Karachle KP, Stergiou KI. 2008. Length-length and lengthweight relationships of several fish species from the North Aegean Sea (Greece). Journal of Biological ResearchThessaloniki, 10: 149-157.

Karakulak FS, Erk H, Bilgin B. 2006. Length-weight relationships for 47 coastal fish species from the Northern Aegean Sea, Turkey. Journal of Applied Ichthyology, 22: 274-278.

Mater S, Kaya M, Bilecenoğlu M. 2011. Türkiye Deniz Balıkları Atlası (4th ed). Ege Üniversitesi Basımevi, İzmir, Turkey, 169 p.

Micale V, Genovese L, Guerrera MC, Laurà R, Maricchiolo G, Muglia U. 2011. The reproductive biology of Pagellus bogaraveo, a new candidate species for aquaculture. The Open Marine Biology Journal, 5: 42-46.

Navarro MR, Villamor B, Myklevoll S, Gil J, Abaunza P, Canoura J. 2012. Maximum size of Atlantic mackerel (Scomber scombrus) and Atlantic chub mackerel (Scomber colias) in the Northeast Atlantic. Cybium, 36: 406-408. 
Nelson, JS. 2006. Fishes of the World ( $4^{\text {th }}$ ed). John Wiley \& Sons, Inc., New York, $601 \mathrm{p}$.

Özaydın O, Uçkun D, Akalın S, Leblebici S, Tosunoğlu Z. 2007. Length-weight relationships of fishes captured from Izmir Bay, Central Aegean Sea. Journal of Applied Ichthyology, 23: 695-696.

Papaconstantinou C, Politou CY, Caragitsou E, Stergiou KI, Mytilineou Ch, Vassilopoulou V, Fourtouni A, Karkani M, Kavadas S, Petrakis G, Siapatis A, Chatzinikolaou P, Giagnisi M. 1994. Investigations on the abundance and distribution of demersal stocks of primary importance in the Thermaikos Gulf and the Thracian Sea (Greece). National Centre for Marine Research, Athens, Greece, Technical Report, North Aegean Series 4/356 p.
Pavlidis MA, Mylonas CC. 2011. Sparidae - Biology and Aquaculture of Gilthead Sea Bream and Other Species. John Wiley \& Sons, Ltd., West Sussex, UK, 390 p.

Santini F, Carnevale G, Sorenson L. 2014. First multi-locus timetree of seabreams and porgies (Percomorpha: Sparidae). Italian Journal of Zoology, 81(1): 55-71.

Sarı E, Çağatay MN. 2001. Distributions of heavy metals in the surface sediments of the Gulf of Saros, NE Aegean Sea. Environment International, 26: 169-173.

Spedicato MT, Greco S, Sophronidis K, Lembo G, Giordano D, Argyri A. 2002. Geographical distribution, abundance and some population characteristics of the species of the genus Pagellus (Osteichthyes: Perciformes) in different areas of the Mediterranean. Scientia Marina, 66 (Suppl 2): 65-82.

Wheeler A, 1997. Pocket Guide to Saltwater Fishes of Britain and Europe. Parkgate Books Ltd. 102 p. - ISBN: 1855853647 